\title{
2 Vezes 5 Vezes Favela: aproximações e distan- ciamentos do cinema brasileiro
}

\section{Roberto Elísio dos Santos*}

\section{Resumo}

Este texto versa sobre a temática social no cinema brasileiro e tem como objeto dois filmes que, realizados com quase 50 anos de diferença, são ambientados em favelas do Rio de Janeiro e abordam os problemas sociais vividos pela população excluída nos grandes centros urbanos. Para compreender as semelhanças e diferenças entre as duas produções, procedeu-se ao estudo comparativo, realizado segundo a análise estrutural da narrativa, a partir do qual foi possível concluir que nessas obras existem semelhanças quanto ao eixo temático, à linearidade e ao realismo documental, mas também distinções em relação à maneira como apresentam a população favelada e quanto ao tom.

Palavras chave: Cinema brasileiro. Cinema Novo. Cinema da Retomada. Produção cinematográfica. Temática social.

\section{Times 5 Times Favela: similarities and differences of Brazilian cinema}

\section{Abstract}

This paper addresses the social issues in Brazilian cinema and its corpus consists of two films that, produced with almost 50 years between them, have the slums of Rio de Janeiro as locations and address the social problems of the excluded population of the big urban centers of Brazil. To understand the similarities and differences between the two productions, it was carried out a comparative study, in accordance with the structural analysis of narrative, from which it was possible to conclude that these movies have similarities in relation to the thematic axis, the linearity and documentary realism, but also differ in terms of how the slum population are shown as well as to the tone.

Key words: Brazilian Cinema. New Cinema. Resumption of the Brazilian Cinema. Film production. Social thematic.

* Professor titular do Programa de Mestrado em Comunicação e da Escola de Comunicação, Pró-Reitoria de Pesquisa e Graduação da Universidade Municipal de São Caetano do Sul (USCS), São Caetano do Sul-SP, Brasil. Jornalista, com pós-doutorado em Comunicação pela ECA-USP e autor dos livros Cinema: arte e documento, As Teorias da Comunicação: da fala à internet, entre outros.

E-mail: roberto.elisio@uscs.edu.br 


\section{Veces 5 Veces Favela: similitudes y diferencias del cine brasileño}

\section{Resumen}

Este trabajo se ocupa de cuestiones sociales en el cine brasileño y tiene como objeto dos películas que, hizo casi 50 años de diferencia, muestran los barrios pobres de Río de Janeiro y se ocupan de los problemas sociales experimentados por la población excluida en los grandes centros urbanos. Para entender las similitudes y diferencias entre las dos producciones, se procedió a un estudio comparativo, hecho de acuerdo con el análisis estructural del relato, de lo cual se concluyó que estas obras son similares en relación con el tema, la linealidad y el realismo documental, pero también difieren en la forma en que se presenta la población de barrios marginales y en relación con el tono.

Palabras clave: Cine Brasileño. Cinema Nuevo. Cinema Brasileño de la retomada. Producción cinematográfica. Temáticas Sociales.

\section{Introdução}

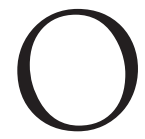

intuito deste trabalho, realizado a partir de pesquisa conduzida no âmbito do Grupo de Pesquisa Gêneros Ficcionais e Cultura Midiática, é analisar duas produções cinematográficas brasileiras, os filmes Cinco Vezes Favela e 5 x favela - agora por nós mesmos, lançados, respectivamente, em 1962 e 2010. O primeiro integrou o ciclo conhecido como Cinema Novo e o segundo faz parte do chamado Cinema da Retomada. Ambos tratam de questões sociais e ambientam-se nas favelas localizadas nos morros do Rio de Janeiro, lugar em que as contradições da sociedade brasileira afloram. Assim, a pergunta-problema que norteou este estudo é: de que forma as duas narrativas fílmicas, separadas por cinco décadas, tratam a população marginalizada? E a hipótese defendida é que, embora abordem questões sociais semelhantes, essas obras diferenciam-se por carregar as marcas de seu tempo histórico e do fazer cinematográfico.

Para evidenciar as diferenças e semelhanças existentes entre esses produtos culturais, foi realizada uma pesquisa de nível exploratório de cunho documental e de conteúdo. O corpus do trabalho consiste nos filmes brasileiros Cinco Vezes Favela (1962) e 5 x favela - agora por nós mesmos (2010). A análise de conteúdo empreendida neste trabalho ancora-se na concepção de Barthes (2008, p.21) de 
análise estrutural da narrativa como "um procedimento dedutivo". Com base nessa concepção teórica e metodológica, foram criadas categorias - os eixos temático, histórico e formal - que permitem entender como o cinema brasileiro aborda a exclusão social e a miséria em dois momentos históricos diferentes. $\mathrm{O}$ eixo temático de ambos os filmes concentra-se na apresentação de situações que envolvem habitantes das favelas cariocas. Já o eixo histórico (recorte sincrônico) refere-se às conjunturas em que as películas foram realizadas e no eixo formal se inserem elementos técnicos e estéticos do cinema, como o tom, a narrativa e a montagem.

Análogos na temática, e afastados no tempo, os filmes podem ser entendidos no mesmo sentido que Stam (2008, p.21-22), com base em Gerard Genette, compreende as adaptações fílmicas: como "hipertextos nascidos de hipotextos preexistentes", que mantêm um jogo intertextual de referências com textos que geram outros textos. No caso específico, não se trata de um remake nem de continuação, mas de duas visões cinematográficas que transitam no mesmo universo social.

Antes de empreender a análise dos filmes, faz-se necessário abordar a maneira como a realidade nacional tem sido captada e lançada às telas por cineastas brasileiros. Além disso, como os filmes constituem projetos culturais diferentes apesar de complementares, é preciso discutir os movimentos Cinema Novo e Cinema da Retomada, em que as duas produções se inserem.

\section{A temática social no cinema brasileiro}

Já na década de 1930, imagens da realidade brasileira, com suas contradições sociais e dos espaços de exclusão, estavam presentes nos filmes. Produções escritas, dirigidas e produzidas por Humberto Mauro e Adhemar Gonzaga apresentavam, ainda que de forma ingênua e romântica, tais aspectos, a exemplo de Favela dos meus amores (1935). Da mesma forma, os dramas sociais realizados pela Atlântida Cinematográfica nos anos 1940 focaram questões sociais e raciais. É o caso de Moleque Tião (1943), dirigido por José Carlos Burle, que tinha como protagonista - e inspirador da história - o ator Grande Otelo. Essa produção, a primeira re- 
alizada pela Atlântida, segundo Fabris (1994, p.63), “ao lado de uma relativa qualidade formal, apesar do baixo custo de produção, apresentava uma temática nacional e popular".

No início da década de 1950, o cinema brasileiro pautava-se pela crescente influência de Hollywood, seja pela tentativa de reproduzir seu glamour, sua forma de produção e sua estética ou pela crítica paródica a seus filmes. Por um lado, produtoras buscavam seguir o padrão hollywoodiano, tido como o caminho a ser trilhado pelo cinema brasileiro, sendo a experiência mais expressiva a da Companhia Vera Cruz (1949-1954). Por outro lado, as chanchadas - comédias, normalmente musicais, destinadas a uma plateia popular - realizadas pela Atlântida evocavam a impossibilidade de implantação de uma indústria cinematográfica no país naquela época. As paródias feitas a filmes norte-americanos, especialmente Matar ou correr e Nem Sansão nem Dalila (ambos de 1954), evidenciavam as dicotomias entre as duas cinematografias.

Outra tendência nascente do cinema brasileiro daquele momento deriva da influência do Neorrealismo italiano - movimento cinematográfico surgido na Itália no pós-guerra e que tinha como objetivo retratar a realidade europeia. A proposta neorrealista, embora fosse marcada pela ambiguidade política inerente à visão de cada diretor e da própria situação da Itália naquele momento, possuía algumas características que a diferenciavam da produção fílmica de Hollywood: uso de locações reais, emprego de não atores ao lado de atores profissionais, produções de baixo orçamento, nas quais predomina a colaboração por parte dos envolvidos no filme e o estilo documental permeando a narrativa ficcional. Sobre este aspecto, Turner (1997, p.42) afirma que os filmes neorrealistas "parecem documentários; apresentam um aspecto granuloso, pouco iluminado, ao contrário da imagem uniformemente iluminada e lustrosa dos clássicos filmes de ficção da época".

No que se refere ao cinema brasileiro, o Neorrealismo italiano, segundo Fabris (2003, p.78-79),

[...] mais do que oferecer modelos estéticos, vinha fornecer uma atitude moral, ao mostrar como debruçar-se sobre a realidade local, principalmente sobre o mundo popular, com um novo olhar. Ao valorizar a postura ética sobre a técnica, as teorias neorrealistas (sobretudo as de Cesare Zavattini) 
[...] foram um elemento deflagrador a mais na busca incessante de uma identidade nacional.

De fato, não se tratou de simplesmente transplantar a experiência italiana do pós-guerra para o nosso país, também porque alguns dos filmes brasileiros, que foram colocados sob a égide do neorrealismo, nem sempre poderiam ser classificados como tais a tout court.

Essa autora (1994, p.37) identifica 1947 como o ano em que o Neorrealismo italiano chegou ao país, mas ressalva que, "mesmo antes dessa data, porém, a fama do Neorrealismo - na ocasião já laureado em Cannes e aclamado em Nova Iorque - havia alcançado o Brasil, pois suas realizações eram aguardadas com grande expectativa”. Pode-se acrescentar a essa constatação que a influência desse movimento no cinema brasileiro também se deu por meio do roteirista italiano Cesare Zavattini, que proferiu palestras e ministrou cursos.

A preocupação em retratar a realidade das classes desfavorecidas, tal como se fazia no cinema neorrealista italiano, pode ser verificada em três experiências cinematográficas brasileiras da década de 1950. Rio, 40 Graus (1955), dirigido por Nelson Pereira dos Santos, apresenta várias histórias que ocorrem em um mesmo dia no Rio de Janeiro, então capital do país. Uma das tramas acompanha os meninos que moram na favela do morro e sobrevivem vendendo amendoins torrados pelas ruas da cidade. Já Rio, Zona Norte (1957), também de Nelson Pereira dos Santos, conta em flashback a trajetória de um compositor popular oriundo do subúrbio carioca. De acordo com Fabris (1994, p.82):

De fato, em seu filme de estreia (mas, sob muitos aspectos em Rio, Zona Norte), Nelson Pereira dos Santos valia-se dos postulados zavattinianos e rosselinianos - por exemplo, a opção pelos deserdados da sorte que, no seu caso, passava também pela questão racial; a escolha de uma técnica de filmagem que permitisse a captação mais imediata da realidade; o próprio título do filme, composto de três elementos, como o de Roma, Cidade Aberta etc. - para acertar os ponteiros com o cinema nacional.

Seguindo a mesma concepção que Nelson Pereira dos Santos, em 1958 o cineasta paulista Roberto Santos realizou o filme O Grande momento. Nele, o protagonista, um jovem desempregado 
morador de um bairro operário, precisa levantar dinheiro para pagar as dívidas do casamento. A experiência neorrealista foi fundamental para a formulação do Cinema Novo, movimento estético e político surgido no início da década de 1960.

\section{Cinema Novo e o Cinema da Retomada}

O acirramento das posições políticas decorrente da Guerra Fria marcou a concepção de cinema (entendido como uma arte engajada na transformação de uma realidade marcada por grandes contrastes sociais) dos anos 1960. Aprofundando a concepção neorrealista, os cineastas brasileiros passaram a apontar suas câmeras para as camadas mais pobres da população e para os ambientes (favela e sertão nordestino) caracterizados pela miséria e pelo abandono por parte do Estado e da sociedade. Esse ciclo de cinema, interrompido pelos rigores da ditadura militar implantada em 1964, ficou conhecido como Cinema Novo.

Setores progressistas da sociedade brasileira realizaram, no início da década de 1960, atividades culturais (peças de teatro e filmes) com conteúdos que denunciavam a situação de miséria vivida por um amplo setor da sociedade brasileira. Além disso, esses artistas e intelectuais pretendiam engendrar uma "cultura nacional e popular". Diversos movimentos (como o Movimento de Cultura Popular de Recife, os grupos de teatro Arena e Oficina, por exemplo) procuraram criar uma forma de cultura nacional e popular, engajada na transformação de uma sociedade opressora e desigual. O conteúdo dessas manifestações culturais deveria atrair e conscientizar as camadas mais pobres da população, mas era idealizada e produzida por intelectuais e estudantes de classe média. Nesse sentido, Carlos Estevam Martins (1980, p.77-80) relata o surgimento do Centro Popular de Cultura da União Nacional dos Estudantes, a partir dos debates realizados no interior do Grupo de Teatro de Arena e da influência do ISEB (Instituto Superior de Estudos Brasileiros):

O CPC começa sob o impacto da presença do ISEB. Isso num primeiro momento, mas, com o tempo, a ligação se inverteu: o CPC passa a influenciar 
o ISEB. O ISEB muda, pelo menos em parte, sua linha de trabalho: se antes seu público é um público de elite, após o surgimento do CPC o ISEB lança duas coleções para o público popular: os Cadernos Brasileiros, produzidos pelo ISEB e editados por Ênio Silveira, e a História Nova, feito por gente ligada ao CPC e por Nelson Werneck Sodré, onde se pretendia contar a história do Brasil a partir do ponto de vista das classes populares e através de uma linguagem popular.

Peças de teatro, manifestações ocorridas nas ruas, festas e apresentações musicais seguiam a diretriz de dialogar com as pessoas comuns e despertar o senso crítico diante de uma realidade injusta. $\mathrm{O}$ mesmo foi feito no cinema brasileiro: pretendia-se fazer filmes populares, questionadores e, ao mesmo tempo, identificados com a cultura nacional (em oposição ao cinema estrangeiro, notadamente o norte-americano) e com as questões que afligiam o país naquele momento.

Do ponto de vista teórico e estético, o Cinema Novo pautouse pela "Estética da Fome" proposta pelo cineasta Glauber Rocha. Seguindo as ideias do sociólogo antilhano Frantz Fanon (2006), que apregoava ser a violência a resposta do colonizado ao colonizador, o diretor brasileiro propunha que "somente uma cultura da fome, minando suas próprias estruturas, pode superar-se qualitativamente: e a mais nobre manifestação cultural da fome é a violência" (1981, p.31). Dessa forma, o cinema brasileiro deveria distanciar-se das fórmulas e da estética de Hollywood e expor a miséria e a violência de um país de Terceiro Mundo. Sem empregar artifícios típicos da indústria cinematográfica, os filmes procuravam usar a luminosidade típica do país e a fotografia dos documentários da época para dar mais realismo ao relato. No entender do crítico Paulo Emílio Salles Gomes (1980, p.83), esse movimento, “apesar de ter escapado tão pouco a seu círculo" (intelectuais de esquerda), criou uma "imagem visual e sonora, contínua e coerente, da maioria absoluta do povo brasileiro".

À exceção de Cinco vezes favela, cujos episódios ambientamse nas favelas cariocas, os filmes do Cinema Novo registravam o Nordeste, região mais pobre do Brasil, atingida pela falta de chuva e pelo autoritarismo e corrupção das autoridades. Nesse cenário são realizados Vidas Secas, Os Fuzis e Deus e o Diabo na Terra do Sol. Mas, 
com o golpe militar de 1964, e principalmente após a censura imposta após a promulgação do Ato Institucional número 5, os cineastas cinemanovistas passaram a abordar a crise da intelectualidade urbana (O Desafio), adaptaram romances para o cinema (São Bernardo, Macunaíma) e dirigiram filmes históricos (Os Inconfidentes).

Criada em 1969 pelo governo militar, a empresa estatal Embrafilme foi responsável, por um lado, pelo fomento do cinema brasileiro ao longo de mais de duas décadas, mas também serviu para controlar o conteúdo, em um tempo marcado pela repressão e pela censura, os tipos de filmes por ela produzidos. Segundo Leite (2005, p.111-113): "Desde sua criação até sua extinção, no início dos anos 1990, a Embrafilme se tornou a principal referência da produção cinematográfica do país. A empresa foi idealizada pelo poderoso ministro do regime militar Roberto Campos". Para esse autor, entre as atribuições da estatal foram se somando a distribuição e a divulgação do filme brasileiro no exterior e no território brasileiro e o financiamento de filmes.

Na década de 1970 a Embrafilme acumulou sucessos de bilheteria (Dona Flor e seus dois maridos, A Dama do Lotação, Xica da Silva, além de filmes estrelados pelos Trapalhões). Mas, nos anos 1980, em virtude da crise econômica, que levou a um descontrole inflacionário, e do processo de redemocratização da sociedade, houve um esvaziamento político e econômico do órgão, que culminou com seu fechamento durante o governo Collor. De acordo com Leite (2005, p.117-118):

O caos financeiro atingiu diretamente a produção cinematográfica do país, fosse ela patrocinada por capital estatal ou privado. Nesse cenário, os déficits orçamentários e os cortes de verbas para a cultura não tardaram a atingir em cheio a Embrafilme. Além da retenção de investimentos, a crise se manifestou de forma aguda com a forte diminuição de público nos cinemas, o que afetou diretamente a arrecadação da empresa estatal. [...]

O processo de esvaziamento da Embrafilme teve continuidade com a Nova República. [...] A Embrafilme estava em processo de deterioração havia um tempo, pois o modelo de produção para o qual fora criada se esgotara. $\mathrm{O}$ governo Collor deu o tiro de misericórdia. Porém, não criou mecanismos que ocupassem seu papel e atuassem no sentido de viabilizar a produção de filmes brasileiros. O discurso oficial apontava para a necessidade do cinema nacional se inserir na lógica do mercado, como pregavam as políticas neoliberais então na ordem do dia. 
Após o final da Embrafilme, a produção cinematográfica no país caiu a níveis baixos. Mas, em meados da década de 1990, com a aprovação de leis de incentivo, como a Lei Rouanet, novos filmes começaram a ser realizados. O sucesso de Carlota Joaquina - Princesa do Brazil, dirigido em 1995 por Carla Camurati, marcou o início do chamado Cinema da Retomada, que, na visão de Butcher (2005, p.14), "designa o processo de recuperação da produção cinematográfica no Brasil depois de uma de suas mais graves crises, no começo dos anos 1990”.

Em conformidade com a postura neoliberal da época, a produção de cinema passou a ser orientada por uma "visão de mercado". A criação, em 1997, da Globo Filmes - departamento especializado em cinema pertencente às Organizações Globo, conglomerado de mídia que engloba rede de televisão, jornal, editora de revistas, emissoras de rádio etc. - intensifica essa postura. Nessa linha, são realizados filmes que adaptam para a tela grande seriados televisivos (A Grande Família, Os Normais), peças de teatro de apelo popular (A partilha, Divã), textos literários conhecidos (O Auto da Compadecida), assim como comédias (Se eu fosse você) e dramédias urbanas (Redentor), tendo no elenco atores e atrizes que atuam nas teledramaturgias da emissora, principalmente nas telenovelas.

Mas, paralelamente a esse cinema comercial, são feitas experiências regionais (Cinema, aspirinas e urubus) e são produzidos filmes voltados para plateias infantis e adolescentes, além de documentários. Dentro e fora da perspectiva dos filmes realizados para o mercado, são encontradas produções que abordam temas sociais, em especial a violência que caracteriza os bolsões de miséria dos grandes centros urbanos (Rio de Janeiro e São Paulo). Obras ficcionais como Cidade de Deus (2002), Carandiru (2003), Linha de passe (2008), Salve Geral e Última parada 174, ambos de 2009, além de documentários (Notícias de Uma Guerra Particular, Ônibus 174), exploraram a carência das populações marginalizadas pela sociedade vítimas da violência resultante da criminalidade crescente, normalmente ligada ao tráfico de entorpecentes. Dessa forma, a realidade da exclusão volta às telas, muitas vezes associada a uma nova tendência do gênero policial, como o polêmico Tropa de Elite (2007). O filme 5 x favela - agora por nós mesmos insere-se 
na linha dos filmes de temática social do cinema realizado após a retomada do século 21 e, em vários segmentos, utiliza elementos da narrativa policial.

\section{Cinco Vezes Favela e 5 x favela - agora por nós mesmos: correlações}

A análise comparativa dos filmes lançados em 1962 e 2010 envolve os eixos temático, histórico (a partir do qual as condições específicas orientam a postura ideológica que norteia a obra cinematográfica) e formal (abarcando o tom ${ }^{1}$, a narrativa e a montagem). Como cada produção é formada por cinco episódios, o procedimento adotado neste trabalho foi o de estabelecer relações de semelhança e de diferenciação de episódios específicos de cada filme.

Na produção dos anos 1960, por exemplo, o episódio Um favelado, dirigido por Marcos Farias, mostra o protagonista à procura de emprego para sustentar a família. Sem conseguir trabalho, e vendo a esposa e o filho procurando restos de comida em um aterro sanitário, tentou roubar dinheiro, mas acabou sendo preso. Há nesse segmento uma clara influência do Neorrealismo italiano, seja pela fotografia em preto e branco com aspecto documental, seja pelo argumento que acompanha a trágica jornada de um trabalhador pobre, cuja situação social o levou, em desespero, a cometer um crime, como no filme Ladrões de bicicleta, realizado em 1948 por Vittorio De Sica.

Da mesma forma, no filme do século 21, uma das histórias, Fonte de renda, dirigido por Manaíra Carneiro e Wagner Novaes, também apresenta um jovem que acabara de ingressar na universidade e que precisava driblar a falta de dinheiro. Apesar de trabalhar como ajudante na padaria da favela, seus ganhos eram insuficientes para sustentar a mãe e o irmão menor e para manter

\footnotetext{
${ }^{1}$ Duarte e Freitas (2007, p.3-4), ao analisar a situação comunicativa televisual, consideram a tonalização do discurso como um dispositivo sintático-semântico que se soma às ancoragens de tempo, espaço, aspecto e atores. Para a autora: "Tal dispositivo diz respeito à conferência de um tom ao discurso, isto é, de um ponto de vista a partir do qual sua narrativa quer ser reconhecida”. O tom é responsabilidade da instância da enunciação, "é uma decisão estratégica do(s) enunciador(es)" para que o texto possa interagir com o interlocutor.
} 
os gastos com os estudos. Ele passou, então, a levar cocaína obtida com os traficantes do morro para vender para os colegas de curso. Essa atividade, que o angustia por obrigá-lo a transgredir a lei, quase custou a vida de seu irmãozinho, que ingeriu a droga. A punição surge como consequência do risco de morte da criança e também parte da reação do médico que atendeu o menino e do policial aposentado amigo da família.

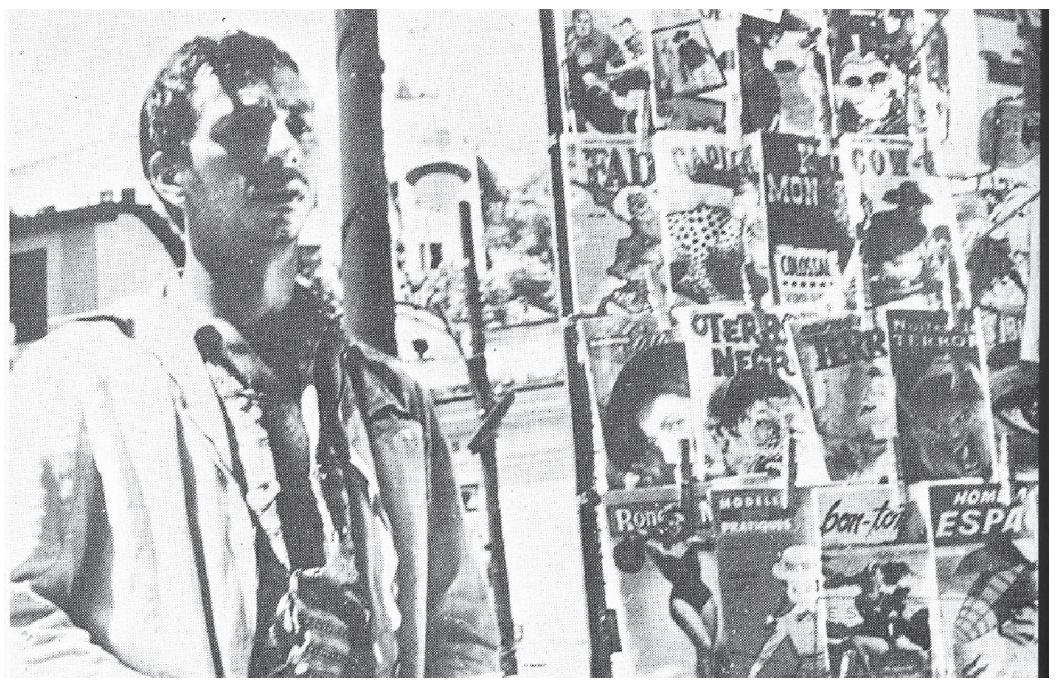

Ilustração 1 - Em Um favelado, a miséria leva ao roubo

Os dois episódios, portanto, estruturam-se a partir da falta de recursos dos personagens, marginais em sua situação econômica, mas não como infratores. Mas diferenciam-se quanto ao enfoque dado a essa trama. No primeiro caso, a denúncia da condição de miséria material obedece a um imperativo ideológico: vítima da injustiça social do sistema, o favelado viu-se impelido a cometer um crime, pelo qual sofreu sanções. Também em Fonte de renda constata-se a desigualdade, mas o envolvimento do protagonista com a contravenção torna-se um dilema ético. Os desfechos das duas narrativas igualmente divergem, pois, na segunda, o personagem conseguiu terminar o curso, sendo o orador de sua turma na formatura. Superada a situação de violação da lei, o favelado pode seguir seu caminho e atingir seu intento de ter formação superior. 
Dois episódios dos filmes de 1962 e de 2010, Couro de gato (com direção de Joaquim Pedro de Andrade) e Arroz com feijão (dirigido por Rodrigo Felha e Cacau Amaral), são focados em crianças que vivem nas favelas. $\mathrm{O}$ primeiro deles parte do costume que havia na época do Carnaval de sacrificar os gatos para a confecção de instrumentos de percussão para serem usados pelas escolas de samba. Os meninos pobres empreendiam a caça aos felinos para ganhar dinheiro. Um deles furtou do jardim de uma mansão um angorá, ao qual se afeiçoa. Acossado pela fome, porém, acabou por vendê-lo ao fabricante de tamborins.

Em Arroz com feijão, um garoto da favela quer comprar um frango para dar de presente para o pai, que reclama do fato de ter de comer arroz e feijão todos os dias. Com a cumplicidade de um amigo, o menino fez pequenos trabalhos (lavou um carro, recolheu esterco de cavalos), mas não conseguiu o dinheiro para comprar o frango. Ele, então, roubou uma galinha da avicultura. Da mesma forma que em Fonte de renda, a transgressão tornou-se um dilema ético: para se redimir, o garoto procurou ressarcir o proprietário da avícola.

Os dois enredos têm em

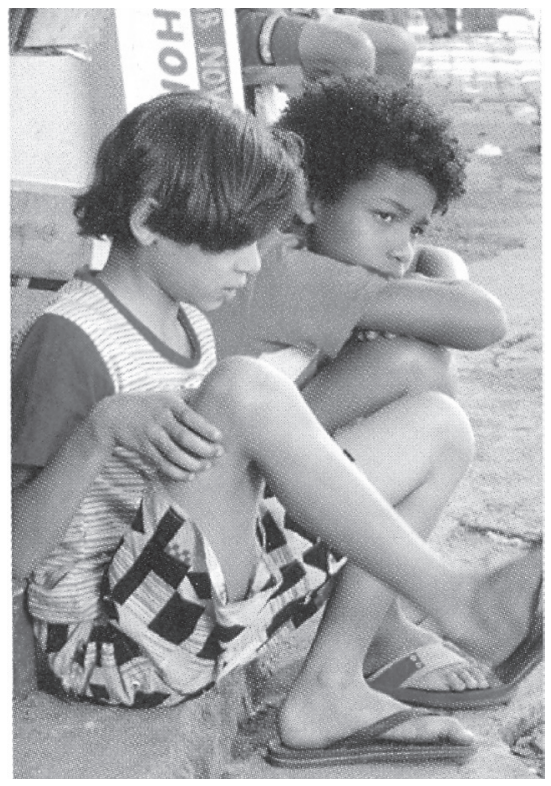

Ilustração 2 - Os protagonistas de Arroz com feijão comum o esforço dos meninos da favela para obter dinheiro. Sua ação é impulsionada pela situação de carência. O episódio de 1962, assim como Um favelado, assume um discurso de denúncia do desamparo a que os personagens estão submetidos. Ao lado da visão realista que capta esse drama, há momentos poéticos e de humor. Já na produção de 2010, o tom é humorístico na quase totalidade do enredo, embora os actantes 
também vivam em condição de pobreza. Se no primeiro o delito (o roubo de gatos para a fabricação de tamborins) é uma consequência da situação de miséria em que vivem os meninos e, portanto, justificável, no segundo, a infração (a subtração do frango da avícola) assume um sentido moral: a falta de recursos não é desculpa para a infração da lei. Os desfechos também são diferentes, pois o primeiro comove o espectador e o segundo o diverte.

Solidariedade e união (ou desunião) da população favelada são questões presentes em alguns episódios do filme de 1962. Em Zé da Cachorra, dirigido por Miguel Borges, o grileiro pretendia desalojar uma família do lugar. O líder da comunidade interferiu, mas ao constatar a passividade e a omissão dos moradores, acabou por expulsálos da favela. Da mesma forma, o episódio Escola de Samba Alegria de Viver, que teve Carlos Diegues na direção, opõe a escola de samba (mostrada como fonte de alienação) ao sindicato de trabalhadores (espaço de conscientização e de integração da população pobre e trabalhadora). No sentido contrário, Pedreira de São Diogo, de Leon Hirszman, apoia-se na coesão dos favelados e de trabalhadores da pedreira para impedir que as explosões derrubem os barracos do

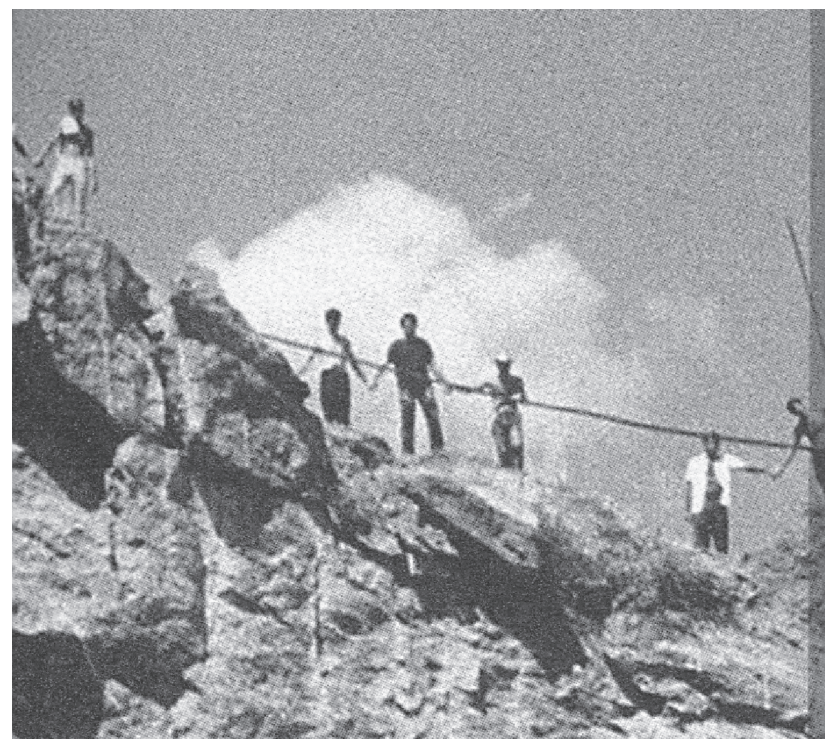

Ilustração 3 - Pedreira de São Diogo mostra a união dos favelados 
morro. O suspense é criado por conta da ação de uma moradora da favela para arregimentar os favelados para se posicionarem na beirada antes que os explosivos sejam detonados.

O filme de 2010 também trata dos temas destacados acima. O episódio Acende a luz, dirigido por Luciano Bezerra, se passa na véspera de Natal e é ambientado em uma favela que está sem energia elétrica devido a um defeito no equipamento de transmissão. O empenho dos moradores leva ao restabelecimento, ainda que precário, da luz. De forma semelhante a Pedreira de São Diogo, a solidariedade entre os moradores e o funcionário da empresa de energia possibilitou a superação do problema que impedia a realização da festa natalina. Mas, diferentemente do episódio de 1962, essa cumplicidade não se dá pelo viés ideológico, mas pelo humano. Solitário, o técnico da fornecedora de energia desenvolveu, ao longo da trama, um laço de amizade com os habitantes da comunidade, que, no início, o tratavam com hostilidade, mas, no final, o acolheram na comemoração.

A cisão entre os moradores da favela, mostrada em Concerto para violino, com direção de Luciano Vidigal, e Deixa voar, de Cadú Barcelos, está centrada na violência gerada pelo tráfico de entorpecentes e pelas quadrilhas que ocupam essas comunidades. Esse aspecto identifica os dois episódios com os filmes da Retomada, que abordam a presença da criminalidade nos espaços de exclusão das grandes cidades, as favelas e os bairros de periferia.

A primeira trama leva ao confronto três amigos de infância. Outrora companheiros de brincadeiras, na idade adulta se encontravam em lados diferentes: um deles se tornou policial corrupto, outro lidera o grupo de criminosos que roubou armas do quartel do primeiro e, entre eles, a garota por quem os dois se afeiçoavam e que se tornou mulher do segundo. Para recuperar as armas furtadas, o policial se alia a outra facção, que pretende dominar a favela. A história é pontuada por flashes (recordações) das três crianças brincando ou por imagens da garota, já crescida, que tocava violino em uma orquestra da comunidade. Essas passagens, poéticas e até piegas, fazem o contraponto para a violência e para a divisão interna da favela e dos protagonistas, que leva irremediavelmente à tragédia.

Deixa voar mistura romantismo à cisão de uma comunidade separada por um rio. De maneira diferente de Concerto para vio- 
lino, a violência e o domínio de diferentes bandos são questões apenas insinuadas. Um adolescente gosta de uma colega de escola, mas ela mora do outro lado da ponte, onde é perigoso se aventurar. Obrigado a reaver uma pipa que caiu naquele lugar, o jovem conta com a ajuda de um morador da outra parte da favela, que está interessado em sua irmã. Além disso, consegue visitar a menina pela qual está apaixonado. O desfecho apon-

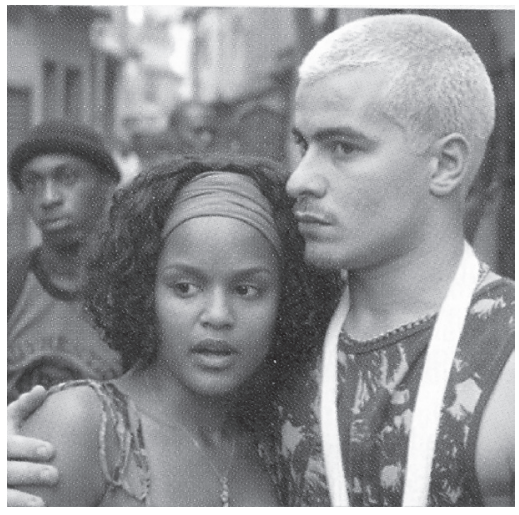

Ilustração 4 - No episódio Concerto para violino, a violência separa as pessoas ta para uma possível harmonia entre os dois lados da favela, possibilitado pela prevalência das relações afetivas sobre as restrições impostas pela violência.

\section{Conclusões}

A análise comparativa das duas obras cinematográficas aponta para aproximações e distanciamentos entre elas. Apesar de partilharem semelhanças no que concerne à temática, cada uma delas está inserida em um tempo histórico diferente. Do ponto de vista sincrônico, o projeto político e estético do Cinema Novo estava intimamente relacionado à radicalização ideológica do início da década de 1960; já a produção contemporânea do cinema brasileiro reflete um contexto marcado pela multiplicidade cultural, pela globalização desenfreada e por uma complexidade maior da sociedade brasileira. Essa situação é descrita por Butcher (2005, p.68):

Uma das grandes dificuldades de qualquer análise do cinema da retomada é encontrar um denominador comum aos filmes realizados a partir desse novo modelo de produção. "Diversidade" é a palavra mais recorrente para descrever o período (...). Não há projeto unificador que anule as diferenças dos filmes entre si, e por mais que guardem pontos comuns (como o fundo político dos filmes do Cinema Novo), todos continuarão sendo obras singulares. No caso do Cinema Novo, aliás, a busca de uma visão totalizante muitas vezes atropelou a diversidade do movimento. 
No que concerne ao eixo temático, tanto Cinco Vezes Favela como $5 x$ favela - agora por nós mesmos têm em comum o foco na situação de exclusão da população favelada do Rio de Janeiro, mas, no primeiro filme, o olhar sobre esse segmento social é externo e vinculado a uma concepção predeterminada. $O$ segundo, como o próprio subtítulo indica, partiu da concepção dos próprios moradores dessas comunidades, ainda que os realizadores tenham participado de oficinas e recebido orientações de cineastas e atores do Cinema Novo (como Carlos Diegues, Ruy Guerra e Hugo Carvana). Além disso, o tratamento dado às questões sociais na produção de 2010 evidencia que, se as contradições da sociedade se mantiveram e até se agravaram, as relações sociais ficaram mais complexas, o que pode ser percebido nos episódios Fonte de renda e Concerto para violino.

Essa diferença é explicada no eixo histórico: nos anos 1960, em plena Guerra Fria e logo após a Revolução Cubana, as posições políticas se radicalizaram. Vários diretores do Cinema Novo participavam das discussões sobre a situação brasileira e do mundo realizadas pelo Instituto Superior de Estudos Brasileiros (ISEB), entidade que reunia intelectuais progressistas. O cinema - em especial os filmes produzidos em países subdesenvolvidos - era encarado como uma forma de arte essencial para promover as mudanças sociais desejadas pela esquerda. Já no século 21, vivese uma desilusão no que tange à política e a sociedade, cada vez mais marcada pelo individualismo, caracteriza-se pelo aumento da violência, principalmente a gerada pelo tráfico de drogas. Nesse contexto, o cinema é visto como lazer e divertimento.

Quanto ao eixo formal, o filme lançado em 2010 apresenta mudanças relativas ao tom (presença de humor), mas as narrativas permanecem lineares - exceto os momentos poéticos e nostálgicos do episódio Concerto para violino - e, do ponto de vista estético, o realismo documental predomina, mantendo o estilo da obra de 1962. Em termos de produção, o projeto atual contou com a realização de oficinas (de roteiro, direção, interpretação) que subsidiaram o trabalho dos atores e realizadores dos novos episódios. Vistas em conjunto, portanto, as duas obras formam um painel acerca de duas concepções de cinema no Brasil separadas por cinco décadas e também da situação social do país nas duas épocas. 


\section{Referências}

BARTHES, Roland et al. Análise estrutural da narrativa. 5. ed. Petrópolis: Vozes, 2008.

BUTCHER, Pedro. Cinema brasileiro hoje. São Paulo: Publifolha, 2005.

DUARTE, Elizabeth Bastos; FREITAS, Rose Lumertz de. Telejornais: a ruptura tonal com as expectativas do subgênero. E-Compós. São Paulo: Compós, v. 8, p 1-16, abril/2007. Disponível em www.e-compos.org.br. Acesso em: 19 jul. 2011.

FABRIS, Mariarosaria. O Neo-realismo italiano em seu diálogo com o cinema independente brasileiro. Cinemais. Rio de Janeiro: Editorial Cinemais, n. 34, p. 73-82, abril/jun. 2003.

Nelson Pereira dos Santos: um olhar neo-realista? São Paulo:

EDUSP, 1994.

FANON, Frantz. Os condenados da terra. Juiz de Fora: Editora UFJF, 2006.

GOMES, Paulo Emílio Salles. Cinema: trajetória no subdesenvolvimento. Rio de Janeiro: Paz e Terra/Embrafilme, 1980.

LEITE, Sidney Ferreira. Cinema brasileiro: das origens à Retomada. São Paulo: Fundação Perseu Abramo, 2005.

MARTINS, Carlos Estevam. História do CPC. Arte em Revista, a.2, n. 3, p.77-82, mar.1980. São Paulo: Kairós.

ROCHA, Glauber. Revolução do cinema novo. Rio de Janeiro: Alhambra/ Embrafilme, 1981.

STAM, Robert. A literatura através do cinema: realismo, magia e a arte da adaptação. Belo Horizonte: Editora UFMG, 2008.

TURNER, Graeme. Cinema como prática social. São Paulo: Summus, 1997.

Recebido em: 14.12 .2010

Aceito em: 17.07.2011 